\title{
Pengaruh Model Pendidikan Matematika Realistik dan Ekspositori terhadap Hasil Belajar Matematika tentang Bangun Datar Ditinjau dari Kemampuan Numerik pada Siswa Kelas III SD Sekecamatan Kebumen Tahun Ajaran 2017/2018
}

\author{
1,2,3 Universitas Sebelas Maret \\ atussholihah30@yahoo.co.id
}

Mar'atus Sholihah ${ }^{1}$, Joharman ${ }^{2}$, Tri Saptuti Susiani ${ }^{3}$

\section{Article History}

accepted 01/06/2019

\begin{abstract}
This research aims at to prove the effect of difference between realistic mathematics education approach with expository strategy towards mathematics learning outcomes viewed from the numericall competence. Number of sample used in this research is 8 elementary schools in Kebumen sub-district. Techniques of collecting data were numeric ability test and learning outcomes test. Data were analyzed using two-way ANOVA method and further analysis used scheffe test. The result of the analysis shows that: (1) there is a significant difference between realistic mathematics education approach with expository strategy towards mathematics learning outcomes $\left\{F_{\text {obtained }}(3,972)>F_{\text {table }}(3,917)\right\}$, (2) there is a significant difference between the students with high numerical competence and the student with low numerical competence towards mathematics learning outcomes $\left\{F_{\text {obtained }}(30,361)>F_{\text {table }}(3,917)\right\}$, (3) there is an interaction effect between approach learning and numerical competence of students $\left\{F_{\text {obtained }}\right.$ $\left.(7,742)>F_{\text {table }}(3,917)\right\}$, (4) for students having high numeric ability, mathematics learning outcomes of students following realistic mathematics education approach is higher than those following expository strategy $\left\{F_{\text {obtained }}(0,3146)<F_{\text {table }}(3,936)\right\}$, (5) for students having low numeric ability, mathematics learning outcomes of students following expository strategy is higher than those following realistic mathematics education approach $\left\{F_{\text {obtained }}(11,4979)>F_{\text {table }}\right.$ $(3,936)\}$, (6) for the students following realistic mathematics education approach, mathematics learning outcomes of students having high numeric ability is higher than those students having low numeric ability $\left\{F_{\text {obtained }}(39,6218)>F_{\text {table }}(3,936)\right\}$, and $(7)$ for the students following expository strategy, mathematics learning outcomes of students having high numeric ability is higher than those students having low numeric ability $\left\{F_{\text {obtained }}(3,3326)<F_{\text {table }}(3,936)\right\}$.
\end{abstract}

Keywords: mathematics learning outcomes, numeric ability, realistic mathematics education approach, expository strategy

\begin{abstract}
Abstrak
Penelitian ini bertujuan untuk membuktikan adanya pengaruh antara pendekatan pendidikan matematika realistik dengan strategi ekspositori terhadap hasil belajar matematika ditinjau dari kemampuan numerik. Sampel yang digunakan sebanyak 8 sekolah dasar di kecamatan Kebumen. Pengumpulan data menggunakan tes kemampuan numerik dan tes hasil belajar matematika. Data dianalisis menggunakan analisis varian dua jalur dan uji lanjut menggunakan uji scheffe. Hasil penelitian menunjukkan bahwa: (1) terdapat perbedaan signifikan antara pendekatan pendidikan matematika realistik dengan strategi ekspositori terhadap hasil belajar matematika $\left\{F_{\text {hitung }}(3,972)>F_{\text {tabel }}(3,917)\right\}$, (2) terdapat perbedaan signifikan antara siswa yang memiliki kemampuan numerik tinggi dengan siswa yang memiliki kemampuan numerik rendah terhadap hasil belajar matematika $\left\{F_{\text {hitung }}(30,361)>F_{\text {tabel }}(3,917)\right\},(3)$ terdapat interaksi antara pendekatan pembelajaran dengan kemampuan numerik siswa $\left\{F_{\text {hitung }}(7,742)>F_{\text {tabel }}(3,917)\right\}$, (4) untuk siswa yang memiliki kemampuan numerik tinggi, hasil belajar matematika siswa yang mengikuti pendekatan pendidikan matematika realistik lebih tinggi daripada siswa yang mengikuti strategi ekspositori $\left\{\left(F_{\text {hitung }}(0,3146)<F_{\text {tabel }}(3,936)\right\}\right.$, $(5)$ untuk siswa yang memiliki
\end{abstract}


kemampuan numerik rendah, hasil belajar matematika siswa yang mengikuti strategi ekspositori lebih tinggi daripada siswa yang mengikuti pendekatan pendidikan matematika realistik $\left\{\left(F_{\text {hitung }}(11,4979)>F_{\text {tabel }}(3,936)\right\}\right.$, (6) untuk siswa yang menggunakan pendekatan pendidikan matematika realistik, hasi belajar matematika siswa dengan kemampuan numerik tinggi lebih tinggi daripada siswa dengan kemampuan numerik rendah $\left\{F_{\text {hitung }}(39,6218)>F_{\text {tabel }}\right.$ $(3,936)$ \}, dan (7) untuk siswa yang menggunakan strategi ekspositori, hasi belajar matematika siswa dengan kemampuan numerik tinggi lebih tinggi daripada siswa dengan kemampuan numerik rendah $\left\{F_{\text {hitung }}(3,3326)<F_{\text {tabel }}(3,936)\right\}$.

Kata kunci: hasil belajar matematika, kemampuan numerik, pendekatan pendidikan matematika realistik, strategi ekspositori 
Matematika merupakan salah satu disiplin ilmu berupa unsur yang tidak didefinisikan, aksioma, dan dalil-dalil yang setelah dibuktikan kebenarannya berlaku secara umum sehingga dapat meningkatkan kemampuan berpikir dan berargumentasi, memberikan kontribusi dalam penyelesaian masalah sehari-hari dan dalam dunia kerja, serta memberikan dukungan dalam pengembangan ilmu pengetahuan dan teknologi.

Berdasarkan observasi yang telah dilakukan oleh peneliti, peneliti mengidentifikasi adanya masalah yang dialami guru maupun siswa dalam pembelajaran matematika yaitu: (1) pembelajaran masih berpusat pada guru, (2) penggunaan pendekatan dalam pembelajaran masih bersifat abstrak, (3) belum dimanfaatkannya keaktifan siswa oleh guru, (4) perbedaan sikap antusias siswa yang berkemampuan numerik tinggi dengan siswa yang berkemampuan numerik rendah dalam pembelajaran, serta (5) penggunaan media yang masih belum maksimal dalam pembelajaran matematika.

Untuk mengatasi permasalahan tersebut, peneliti mencoba menggunakan pendekatan Pendidikan Matematika Realistik (PMR). Pendidikan matematika realistik adalah suatu cara dalam pembelajaran matematika yang menghubungkan aktivitas manusia dengan kehidupan sehari-hari siswa sebagai sumber pengetahuan. Jadi, dalam pendekatan pendidikan matematika realistik ini, materi yang diajarkan kepada siswa dikaitkan dengan aktivitas dalam kehidupan sehari-hari dan menggunakan media yang konkret untuk mempermudah siswa dalam menerima materi pelajaran.

Selain menggunakan pendekatan pendidikan matematika realistik, peneliti juga menggunakan strategi ekspositori. Strategi ekspositori adalah strategi yang menekankan pada proses penyampaian materi secara verbal oleh guru kepada siswa agar siswa menguasai materi pelajaran secara optimal (Sanjaya, 2012: 179).

Setiap siswa pasti memiliki kemampuan numerik yang berbeda. Menurut Nurkancana (Sunarthi, Dantes, dan Tika, 2015: 3), "kemampuan numerik adalah kemampuan yang dimiliki siswa dalam melakukan operasi hitung secara manual yang meliputi operasional penjumlahan, pengurangan, perkalian, pembagian, perpangkatan, penarikan akar, dan lainnya yang memungkinkan untuk berkembang dan berprestasi di bidang matematika." Kemampuan numerik dibedakan menjadi 2, yaitu kemampuan numerik tinggi dan kemampuan numerik rendah. Menurut Sumarnaya (Astuti, Marhaeni, dan Sariyasa, 2013: 7), siswa yang memiliki kemampuan numerik tinggi memiliki ciri-ciri: "(1) yakin dengan kemampuannya untuk mengatasi masalah, (2) merasa setaraf dengan orang lain, (3) lebih mudah dan cepat dalam mengambil perhitungan-perhitungan berupa angka, (4) mampu memperbaiki dirinya dan berusaha untuk mengubahnya, dan (5) mempunyai tingkat penguasaan lebih tinggi." Sedangkan siswa memiliki kemampuan numerik rendah memiliki kepercayaan diri yang rendah terhadap kemampuannya dalam menyelesaikan tugas-tugasnya.

Tujuan penelitian ini yaitu: (1) membuktikan adanya pengaruh perbedaan antara pendekatan pendidikan matematika realistik dengan strategi ekspositori terhadap hasil belajar matematika siswa kelas III sekolah dasar sekecamatan Kebumen tahun ajaran 2017/2018, (2) membuktikan adanya pengaruh perbedaan antara siswa yang memiliki kemampuan numerik tinggi dengan siswa yang memiliki kemampuan numerik rendah terhadap hasil belajar matematika siswa kelas III sekolah dasar sekecamatan Kebumen tahun ajaran 2017/2018, dan (3) membuktikan adanya interaksi antara pendekatan pembelajaran dengan kemampuan numerik siswa kelas III sekolah dasar sekecamatan Kebumen tahun ajaran 2017/2018.

\section{METODE}

Dalam penelitian ini, peneliti menggunakan metode quasi eksperimen. Populasi dalam penelitian ini yaitu, seluruh siswa kelas III sekolah dasar sekecamatan Kebumen tahun ajaran 2017/2018, sedangkan sampelnya sebanyak 238 siswa dari 8 sekolah 
dasar yang telah dipilih menggunakan teknik stratified cluster random sampling. Kedelapan sekolah dasar tersebut yaitu: SDN 5 Bumirejo, SDN 6 Panjer, SDN Roworejo, SDN 4 Bumirejo, SDN 2 Kalirejo, SDN 7 Kebumen, SDN 2 Panjer, dan SDN 2 Wonosari.

Teknik pengumpulan data yang digunakan yaitu menggunakan tes kemampuan numerik dan tes hasil belajar matematika. Sebelum tes tersebut digunakan, tes tersebut telah diujicobakan di salah satu sekolah yang tidak menjadi sampel untuk mengetahui tingkat validitas dan reliabilitasnya. Pada tes kemampuan numerik, dari 40 soal pilihan ganda yang diujicobakan, sebanyak 30 soal dinyatakan valid dan 10 soal dinyatakan tidak valid. Pada tes hasil belajar matematika, dari 30 soal pilihan ganda, 23 soal dinyatakan valid dan 7 soal dinyatakan tidak valid. Sedangkan sebanyak 5 soal uraian, dinyatakan valid semua.

Teknik analisis data yang digunakan yaitu menggunakan uji prasyarat (uji normalitas dan uji homogenitas, uji anova dua jalur, dan uji scheffe.

\section{HASIL DAN PEMBAHASAN}

Tabel 4.13 Hasil Uji Anova Dua Jalur

Tests of Between-Subjects Effects

Dependent Variable:PostTest

\begin{tabular}{|c|c|c|c|c|c|}
\hline Source & $\begin{array}{l}\text { Type III Sum } \\
\text { of Squares }\end{array}$ & $d f$ & $\begin{array}{l}\text { Mean } \\
\text { Square }\end{array}$ & $\mathrm{F}$ & Sig. \\
\hline Corrected Model & $7363.138^{a}$ & 3 & 2454.379 & 15.525 & .000 \\
\hline Intercept & 568839.611 & 1 & 568839.611 & 3598.041 & .000 \\
\hline $\begin{array}{l}\text { PendekatanPembe } \\
\text { lajaran }\end{array}$ & 627.958 & 1 & 627.958 & 3.972 & .048 \\
\hline Kelompok & 4799.983 & 1 & 4799.983 & 30.361 & .000 \\
\hline $\begin{array}{l}\text { PendekatanPembe } \\
\text { lajaran * Kelompok }\end{array}$ & 1223.993 & 1 & 1223.993 & 7.742 & .006 \\
\hline Error & 19604.034 & 124 & 158.097 & & \\
\hline Total & 600045.970 & 128 & & & \\
\hline Corrected Total & 26967.172 & 127 & & & \\
\hline
\end{tabular}

a. $\mathrm{R}$ Squared $=, 273$ (Adjusted R Squared $=, 255$ )

Pada tabel di atas, kolom pendekatan pembelajaran menunjukkan pengaruh pendekatan pembelajaran yang digunakan terhadap hasil belajar (post test) siswa. Pada hasil di atas, nilai Sig. $<\alpha(0,048<0,05)$ yang berarti pendekatan pembelajaran yang digunakan berpengaruh signifikan terhadap hasil belajar (post test) siswa.

Pada kolom kelompok menunjukkan pengaruh kemampuan numerik siswa terhadap hasil belajar (post test) siswa. Pada hasil di atas, nilai Sig. $<\alpha(0,000<0,05)$ yang berarti kemampuan numerik berpengaruh signifikan terhadap hasil belajar (post test) siswa.

Pada kolom pendekatan pembelajaran * kelompok menunjukkan pengaruh interaksi antara pendekatan pembelajaran yang digunakan dengan kemampuan numerik terhadap hasil belajar siswa. Pada hasil di atas, nilai Sig. $<\alpha(0,006<0,05)$. Oleh karena nilai Sig. $<\alpha$ berarti terdapat interaksi antara pendekatan dan kemampuan numerik terhadap hasil belajar siswa. Dikarenakan adanya interaksi antara pendekatan pembelajaran dengan kelompok, maka dilakukan uji lanjut menggunakan uji scheffe. Adapun hasil dari uji scheffe dapat dilihat pada tabel berikut ini.

Tabel 4.15 Hasil Uji Scheffe dengan Perhitungan Manual

\begin{tabular}{|l|l|l|l|l|l|}
\hline No. & Sumber Variasi & $\mathbf{d b}$ & $\mathbf{F}_{\text {hitung }}$ & $\mathbf{F}_{\text {tabel }}$ & Keputusan \\
\hline 1. & Pendekatan & 1 & 3,972 & 3,917 & Tolak Ho \\
\hline
\end{tabular}


Volume 7 Nomor 2 Tahun 2019

\begin{tabular}{|l|l|l|l|l|l|}
\hline 2. & Kemampuan numerik & 1 & 30,361 & 3,917 & Tolak Ho \\
\hline 3. & $\begin{array}{l}\text { PMR kemampuan numerik tinggi } \\
\text { dengan PMR kemampuan } \\
\text { numerik rendah }\end{array}$ & 124 & 39,6218 & 3,936 & Tolak Ho \\
\hline 4. & $\begin{array}{l}\text { Ekspositori kemampuan numerik } \\
\text { tinggi dengan ekspositori } \\
\text { kemampuan numerik rendah }\end{array}$ & 124 & 3,3326 & 3,936 & Terima Ho \\
\hline 5. & $\begin{array}{l}\text { PMR kemampuan numerik tinggi } \\
\text { dengan ekspositori kemampuan } \\
\text { numerik tinggi }\end{array}$ & 124 & 0,3146 & 3,936 & Terima Ho \\
\hline 6. & $\begin{array}{l}\text { PMR kemampuan numerik } \\
\text { rendah dengan ekspositori } \\
\text { kemampuan numerik rendah }\end{array}$ & 124 & 11,4979 & 3,936 & Tolak Ho \\
\hline
\end{tabular}

Berdasarkan hasil pengujian hipotesis pertama didapat nilai $F_{\text {hitung }}$ sebesar 3,972 dan nilai $F_{\text {tabel }}$ pada taraf signifikansi 0,05 adalah 3,917 . Nilai $F_{\text {hitung }}(3,972)>$ $F_{\text {tabel }}(3,917)$ sehingga Ho ditolak. Hal ini menunjukkan bahwa terdapat perbedaan hasil belajar matematika antara pendekatan pendidikan matematika realistik dengan strategi ekspositori pada siswa kelas III sekolah dasar sekecamatan Kebumen tahun ajaran 2017/2018. Hasil belajar matematika pada siswa yang menggunakan strategi ekspositori lebih tinggi daripada hasil belajar siswa yang menggunakan pendekatan pendidikan matematika realistik. Secara deskriptif, rata-rata hasil belajar matematika pada siswa yang menggunakan strategi ekspositori yaitu 69,423. Sedangkan nilai ratarata hasil belajar matematika pada siswa yang menggunakan pendekatan pendidikan matematika realistik yaitu 64,958. Hal ini dikarenakan karakteristik siswa kelas III sekolah dasar yaitu masih berpikir pada hal-hal yang konkret, memahami perhitungan sederhana, memiliki rasa ingin tahu yang tinggi, dan memiliki kemampuan memecahkan masalah yang sederhana sehingga mereka masih kesulitan jika diajak menggunakan pendekatan Pendidikan Matematika Realitstik. Salah satu karakteristik strategi ekspositori yaitu materi yang disampaikan merupakan materi pelajaran yang sudah jadi, seperti data atau fakta, dan konsep-konsep tertentu (Sanjaya, 2012: 179). Strategi ekspositori juga efektif digunakan pada sekelompok siswa yang rata-rata memiliki kemampuan rendah. Hal tersebut juga didukung dengan hasil penelitian yang dilakukan oleh Hidayati dan Harini (2016) bahwa pembelajaran dengan menggunakan strategi ekspositori terbukti dapat meningkatkan minat dan prestasi belajar matematika. Dengan demikian, hasil penelitian yang diperoleh telah sesuai dengan teori yang ada dan didukung pula dengan temuan penelitian sebelumnya yang menyatakan bahwa perbedaan hasil belajar matematika antara pendekatan pendidikan matematika realistik dengan strategi ekspositori pada siswa kelas III sekolah dasar sekecamatan Kebumen tahun ajaran 2017/2018.

Berdasarkan hasil pengujian hipotesis kedua didapat nilai $F_{\text {hitung }}$ sebesar 30,361 dan nilai $F_{\text {tabel }}$ pada taraf signifikansi 0,05 adalah 3,917 . Nilai $F_{\text {hitung }}(30,361)>F_{\text {tabel }}$ $(3,917)$ sehingga Ho ditolak. Hal ini menunjukkan bahwa terdapat perbedaan hasil belajar matematika antara siswa yang memiliki kemampuan numerik tinggi dengan siswa yang memiliki kemampuan numerik rendah pada siswa kelas III sekolah dasar sekecamatan Kebumen tahun ajaran 2017/2018. Hasil belajar matematika pada siswa yang memiliki kemampuan numerik tinggi lebih tinggi daripada hasil belajar siswa yang memiliki kemampuan numerik rendah. Secara deskriptif, rata-rata hasil belajar 
matematika pada siswa yang memiliki kemampuan numerik tinggi yaitu 73,473 . Sedangkan nilai rata-rata hasil belajar matematika pada siswa yang memiliki kemampuan numerik rendah yaitu 60,350. Menurut Astuti (2013: 7), hal ini disebabkan prestasi belajar matematika siswa dipengaruhi oleh banyak faktor, baik faktor internal maupun faktor eksternal. Faktor internal merupakan faktor yang berasal dari dalam diri individu salah satunya kemampuan numerik. Kemampuan numerik adalah kemampuan yang dimiliki siswa yang berkaitan dengan kecermatan dan kecepatan dalam melakukan operasi hitung penjumlahan, pengurangan, perkalian, pembagian, perpangkatan, dan penarikan akar secara manual. Kemampuan numerik yang dimiliki siswa ada yang tinggi dan juga ada yang rendah sehingga hasil belajar yang diperoleh antarsiswa juga berbeda-beda. Dengan demikian, dapat disimpulkan bahwa terdapat perbedaan hasil belajar matematika antara siswa yang memiliki kemampuan numerik tinggi dengan siswa yang memiliki kemampuan numerik rendah pada siswa kelas III sekolah dasar sekecamatan Kebumen tahun ajaran 2017/2018.

Berdasarkan hasil pengujian hipotesis ketiga, didapat nilai $F_{\text {hitung }}$ sebesar 7,742 dan nilai $F_{\text {tabel }}$ pada taraf signifikansi 0,05 adalah 3,917 . Nilai $F_{\text {hitung }}(7,742)>F_{\text {tabel }}$ $(3,917)$ sehingga Ho ditolak. Hal ini menunjukkan bahwa terdapat interaksi antara pendekatan pembelajaran dengan kemampuan numerik siswa kelas III sekolah dasar sekecamatan Kebumen tahun ajaran 2017/2018.

Fakta tersebut mengidentifikasikan bahwa kemampuan numerik siswa dalam menerapkan pendekatan pembelajaran yang digunakan mempengaruhi hasil belajar matematika siswa. Hubungan antara karakteristik siswa, kualitas pembelajaran, dan hasil belajar dijelaskan dalam teori belajar Bloom. Inti dari teori ini yaitu bahwa hasil belajar dipengaruhi oleh dua variabel yaitu (1) karakteristik siswa yang meliputi variansi masukan kognitif siswa misalnya kemampuan (abillity) dan variansi masukan afektif (affective entry behavior), seperti motivasi, minat, dan sikap, serta (2) kualitas pembelajaran (quality of instruvtion) yang difokuskan pada interaksi di kelas (Sunarthi, Dantes, dan Tika, 2015: 6). Dalam hal ini, variabel kemampuan numerik siswa dalam pembelajaran matematika turut menentukan pengaruh penerapan pendekatan pembelajaran terhadap hasil belajar matematika. Siswa yang memiliki kemampuan numerik tinggi pada umumnya memiliki cara berpikir yang teratur dan baik dalam mengerjakan sesuatu maupun dalam memecahkan masalah. Hal ini dapat dilihat dari ketertarikan siswa dalam mengolah hal-hal yang berhubungan dengan matematika saat pembelajaran berlangsung. Dengan kemampuan numerik yang dimiliki siswa akan membantu mereka dalam memahami materi, menganalisis setiap permasalahan, dan menerapkan konsep matematika dalam kehidupan sehari-hari. Oleh sebab itu, penerapan pendekatan pembelajaran matematika yang digunakan sangat berkaitan dengan kemampuan numerik siswa.

Hasil penelitian ini sejalan dengan hasil penelitian yang dilakukan oleh Astuti, Marhaeni, dan Sariyasa (2013) bahwa terdapat pengaruh interaksi yang signifikan antara pendekatan pembelajaran dan kemampuan numerik terhadap prestasi belajar matematika. Selain itu, hasil penelitian ini juga dipertegas oleh hasil penelitian yang dilakukan oleh Sunarthi, Dantes, dan Tika (2015) bahwa terdapat interaksi yang signifikan antara pendekatan pembelajaran dengan kemampuan numerik terhadap hasil belajar matematika.

Dengan demikian, hasil penelitian yang diperoleh telah sesuai dengan teori yang ada dan didukung pula dengan temuan beberapa penelitian sebelumnya yang menyatakan bahwa terdapat pengaruh interaksi antara pendekatan pembelajaran dengan kemampuan numerik siswa terhadap hasil belajar matemtika.

Berdasarkan hasil pengujian hipotesis keempat, didapat nilai $F_{\text {hitung }}$ sebesar 0,3146 dan nilai $F_{\text {tabel }}$ pada taraf signifikansi 0,05 adalah 3,936 . Nilai $F_{\text {hitung }}(0,3146)<$ $F_{\text {tabel }}(3,936)$ sehingga Ho diterima. Hasil ini menunjukkan bahwa tidak ada perbedaan hasil belajar matematika antara siswa kemampuan numerik tinggi yang menggunakan 
pendekatan pendidikan matematika realistik dengan siswa kemampuan numerik tinggi yang menggunakan strategi ekspositori pada siswa kelas III sekolah dasar sekecamatan Kebumen tahun ajaran 2017/2018. Hal ini dapat dilihat pada skor ratarata hasil belajar matematika yang memiliki kemampuan numerik tinggi yang menggunakan pendekatan matematika realistik sebesar 74,247 lebih tinggi sedikit daripada skor rata-rata hasil belajar matematika yang memiliki kemampuan numerik tinggi yang menggunakan strategi ekspositori sebesar 72,479.

Menurut Sumarnaya (Astuti, 2013: 7), "Siswa yang memiliki kemampuan numerik tinggi memiliki ciri-ciri: (a) yakin dengan kemampuannya untuk mengatasi masalah, (b) merasa setaraf dengan orang lain, (c) lebih mudah dan cepat dalam mengambil perhitungan-perhitungan berupa angka, (d) mampu memperbaiki dirinya dan berusaha untuk mengubahnya, dan (e) mempunyai tingkat penguasaan lebih tinggi." Oleh karena itu, siswa yang memiliki kemampuan numerik tinggi ketika menggunakan pendekatan pendidikan matematika realistik maupun strategi ekspositori hasil belajarnya akan tetap tinggi.

Berdasarkan hasil pengujian hipotesis kelima, didapat nilai $F_{\text {hitung }}$ sebesar 11,4979 dan nilai $F_{\text {tabel }}$ pada taraf signifikansi 0,05 adalah 3,936 . Nilai $F_{\text {hitung }}(11,4979)$ $>F_{\text {tabel }}(3,936)$ sehingga Ho ditolak. Hasil ini menunjukkan bahwa terdapat perbedaan hasil belajar matematika antara siswa kemampuan numerik rendah yang menggunakan pendekatan pendidikan matematika realistik dengan siswa kemampuan numerik rendah yang menggunakan strategi ekspositori pada siswa kelas III sekolah dasar sekecamatan Kebumen tahun ajaran 2017/2018. Hal ini dapat dilihat pada skor rata-rata hasil belajar matematika yang memiliki kemampuan numerik rendah yang menggunakan pendekatan matematika realistik sebesar 55,669 lebih rendah daripada skor rata-rata hasil belajar matematika yang memiliki kemampuan numerik rendah yang menggunakan strategi ekspositori sebesar 66,368.

Hasil penelitian ini juga sejalan dengan hasil penelitian yang dilaksanakan oleh Sunarthi, Dantes, dan Tika (2015) yang meneliti tentang pengaruh pendekatan pembelajaran matematika realistik terhadap hasil belajar matematika siswa sekolah dasar ditinjau dari kemampuan numerik pada siswa kelas VI gugus sukawati III. Hasil penelitian menunjukkan bahwa siswa yang memiliki kemampuan numerik rendah dan mengikuti pembelajaran matematika dengan pendekatan pembelajaran matematika realistik memiliki perbedaan hasil belajar dengan siswa yang mengikuti pelajaran matematika dengan pembelajaran konvensional.

Seseorang yang memiliki kemampuan numerik rendah memiliki kepercayaan diri yang rendah terhadap kemampuannya dalam menyelesaikan tugasnya. Merujuk pada ciriciri tersebut, diperlukan kegiatan pembelajaran yang memberikan bimbingan dan informasi secara langsung kepada siswa. Berdasarkan temuan dalam penelitian dan hasil penelitian yang terdahulu diperoleh hasil bahwa pembelajaran ekspositori cocok diterapkan untuk siswa yang memiliki kemampuan numerik rendah.

Berdasarkan hasil pengujian hipotesis keenam, didapat nilai $F_{\text {hitung }}$ sebesar 39,6218 dan nilai $F_{\text {tabel }}$ pada taraf signifikansi 0,05 adalah 3,936 . Nilai $F_{\text {hitung }}(39,6218)$ $>F_{\text {tabel }}(3,936)$ sehingga Ho ditolak. Hasil ini menunjukkan bahwa terdapat perbedaan hasil belajar siswa kemampuan numerik tinggi yang menggunakan pendekatan pendidikan matematika realistik dengan siswa kemampuan numerik rendah yang menggunakan pendekatan pendidikan matematika realistik pada siswa kelas III sekolah dasar sekecamatan Kebumen tahun ajaran 2017/2018. Hal ini dapat dilihat pada skor rata-rata hasil belajar matematika siswa kemampuan numerik tinggi yang menggunakan pendekatan pendidikan matematika realistik sebesar 74,247 lebih tinggi daripada skor rata-rata hasil belajar matematika siswa kemampuan numerik rendah yang menggunakan pendekatan pendidikan matematika realistik sebesar 55,669.

Menurut Astuti (2013), kemampuan numerik merupakan salah satu karakteristik peserta didik yang turut berpengaruh terhadap hasil belajar matematika peserta didik. 
Siswa yang memiliki kemampuan numerik yang baik pada umumnya memiliki cara berpikir yang teratur dan baik dalam mengerjakan sesuatu maupun dalam memecahkan masalah. Hal ini dapat dilihat dari ketertarikan siswa dalam mengolah hal-hal yang berhubungan dengan matematika saat pembelajaran berlangsung. Dengan kemampuan numerik yang dimiliki siswa akan membantu mereka dalam memahami materi, menganalisis setiap permasalahan, dan menerapkan konsep matematika dalam kehidupan sehari-hari sehingga hasil belajar yang diperoleh pun baik.

Dengan demikian, terdapat perbedaan hasil belajar matematika siswa kemampuan numerik tinggi yang menggunakan pendekatan pendidikan matematika realistik dengan siswa kemampuan numerik rendah yang menggunakan pendekatan pendidikan matematika realistik.

Berdasarkan hasil pengujian hipotesis ketujuh, didapat nilai $F_{\text {hitung }}$ sebesar 3,3326 dan nilai $F_{\text {tabel }}$ pada taraf signifikansi 0,05 adalah 3,936 . Nilai $F_{\text {hitung }}(3,3326)<$ $F_{\text {tabel }}(3,936)$ sehingga Ho diterima. Hasil ini menunjukkan bahwa tidak ada perbedaan hasil belajar siswa kemampuan numerik tinggi yang menggunakan strategi ekspositori dengan siswa kemampuan numerik rendah yang menggunakan strategi ekspositori pada siswa kelas III sekolah dasar sekecamatan Kebumen tahun ajaran 2017/2018. Hal ini dapat dilihat pada skor rata-rata hasil belajar matematika siswa kemampuan numerik tinggi yang menggunakan strategi ekspositori sebesar 72,479 lebih tinggi daripada skor rata-rata hasil belajar matematika siswa kemampuan numerik rendah yang menggunakan strategi ekspositori sebesar 66,368. Siswa yang kemampuan numeriknya rendah, mereka akan kesulitan dalam melakukan operasi hitung secara manual yang mengakibatkan hasil belajarnya rendah. Sedangkan siswa yang kemampuan numeriknya tinggi, mereka tidak merasa kesulitan dalam melakukan operasi hitung manual sehingga hasil belajarnya tinggi.

\section{SIMPULAN}

Berdasarkan hasil penelitian di atas, maka dapat disimpulkan bahwa: (1) terdapat perbedaan hasil belajar matematika yang signifikan antara model pendidikan matematika realistik dengan model ekspositori yang ditunjukkan dengan nilai $F_{\text {hitung }}$ $(3,972)>F_{\text {tabel }}(3,917)$. Hal ini berarti Ho ditolak sehingga terbukti bahwa terdapat perbedaan hasil belajar matematika antara model pendidikan matematika realistik dengan model ekspositori pada siswa kelas III sekolah dasar sekecamatan Kebumen tahun ajaran 2017/2018, (2) terdapat perbedaan hasil belajar matematika yang signifikan antara siswa yang memiliki kemampuan numerik tinggi dengan siswa yang memiliki kemampuan numerik rendah yang ditunjukkan dengan nilai $F_{\text {hitung }}(30,361)>$ $F_{\text {tabel }}(3,917)$. Hal ini berarti Ho ditolak sehingga terbukti bahwa terdapat perbedaan hasil belajar matematika antara siswa yang memiliki kemampuan numerik tinggi dengan siswa yang memiliki kemampuan numerik rendah pada siswa kelas III sekolah dasar sekecamatan Kebumen tahun ajaran 2017/2018, (3) terdapat interaksi antara model pembelajaran pendidikan matematika realistik dengan kemampuan numerik siswa yang ditunjukkan dengan nilai $F_{\text {hitung }}(7,742)>F_{\text {tabel }}(3,917)$. Hal ini berarti Ho ditolak sehingga terbukti bahwa terdapat interaksi antara model pembelajaran dengan kemampuan numerik pada siswa kelas III sekolah dasar sekecamatan Kebumen tahun ajaran 2017/2018, (4) tidak ada perbedaan hasil belajar matematika antara siswa kemampuan numerik tinggi yang menggunakan model pendidikan matematika realistik dengan siswa kemampuan numerik tinggi yang menggunakan model ekspositori yang ditunjukkan dengan nilai $F_{\text {hitung }}(0,3146)<F_{\text {tabel }}(3,936)$. Hal ini berarti Ho diterima sehingga tidak ada perbedaan hasil belajar matematika antara siswa kemampuan numerik tinggi yang menggunakan model pendidikan matematika realistik dengan siswa kemampuan numerik tinggi yang menggunakan model ekspositori pada siswa kelas III sekolah dasar sekecamatan Kebumen tahun ajaran 2017/2018, (5) terdapat 
perbedaan hasil belajar matematika antara siswa kemampuan numerik rendah yang menggunakan model pendidikan matematika realistik dengan siswa kemampuan numerik rendah yang menggunakan model ekspositori yang ditunjukkan dengan nilai $F_{\text {hitung }}(11,4979)>F_{\text {tabel }}(3,936)$. Hal ini berarti Ho ditolak sehingga terbukti bahwa terdapat perbedaan hasil belajar matematika antara siswa kemampuan numerik rendah yang menggunakan model pendidikan matematika realistik dengan siswa kemampuan numerik rendah yang menggunakan model ekspositori pada siswa kelas III sekolah dasar sekecamatan Kebumen tahun ajaran 2017/2018, (6) terdapat perbedaan hasil belajar siswa kemampuan numerik tinggi yang menggunakan model pendidikan matematika realistik dengan siswa kemampuan numerik rendah yang menggunakan model pendidikan matematika realistik yang ditunjukkan dengan nilai $F_{\text {hitung }}(39,6218)>F_{\text {tabel }}(3,936)$. Hal ini berarti Ho ditolak sehingga terbukti bahwa terdapat perbedaan hasil belajar siswa kemampuan numerik tinggi yang menggunakan model pendidikan matematika realistik dengan siswa kemampuan numerik rendah yang menggunakan model pendidikan matematika realistik pada siswa kelas III sekolah dasar sekecamatan Kebumen tahun ajaran 2017/2018, dan (7) tidak ada perbedaan hasil belajar siswa kemampuan numerik tinggi yang menggunakan model ekspositori dengan siswa kemampuan numerik rendah yang menggunakan model ekspositori yang ditunjukkan dengan nilai $F_{\text {hitung }}(3,3326)<F_{\text {tabel }}(3,936)$. Hal ini berarti Ho diterima sehingga tidak ada perbedaan hasil belajar siswa kemampuan numerik tinggi yang menggunakan model ekspositori dengan siswa kemampuan numerik rendah yang menggunakan model ekspositori pada siswa kelas III sekolah dasar sekecamatan Kebumen tahun ajaran 2017/2018.

\section{DAFTAR PUSTAKA}

Astuti, I.A.K., Marhaeni, A.A.I.N., dan Sariyasa. (2013). Pengaruh Pendekatan Matematika Realistik terhadap Prestasi Belajar Matematika ditinjau dari Kemampuan Numerik, e-Journal Program Pascasarjana Universitas Pendidikan Ganesha Jurusan Pendidikan Dasar, 3, 5 - 6.

Hidayati, I.S dan Eka H. (2016). Meningkatkan Minat dan Prestasi Belajar tentang FPB dan KPK Melalui Strategi Pembelajaran Ekspositori, UNION: Jurnal Pendidikan Matematika, 4 (1), 6.

Sanjaya, W. (2012). Strategi Pembelajaran Berorientasi Standar Proses Pendidikan. Jakarta: Kencana Prenada Media Group.

Sunarthi, N. W., Dantes, N., dan Tika, I. N. (2015). Pengaruh Pendekatan Pembelajaran Matematika Realistik terhadap Hasil Belajar Matematika Siswa Sekolah Dasar ditinjau dari Kemampuan Numerik pada Siswa Kelas VI Gugus Sukawati III, e-Journal Program Pascasarjana Universitas Pendidikan Ganesha Program Studi Penelitian dan Evaluasi Pendidikan, 5 (1), 6. 